\title{
Pemberdayaan Masyarakat Melalui Pengelolaan Limbah di Anak Sungai Citarum
}

\author{
Deni Darmawan ${ }^{1}$ Rita Setiawati $^{2}$, Sekar Hana Triesti K ${ }^{3}$, Ridho Anggoro ${ }^{4}$, Andy Surya $\mathrm{A}^{5}$ \\ 1,2,3,4,5 Universitas Pendidikan Indonesia, Bandung, Indonesia \\ ridho.anggoro35@upi.edu
}

\begin{abstract}
Abstrak
Sampah merupakan material sisa yang tidak di inginkan setelah berakhirnya suatu proses. Sampah didefinisikan oleh manusia menurut derajat keterpakaiannya, dalam proses-proses alam sebenarnya tidak ada konsep sampah, yang ada hanya produk-produk yang dihasilkan setelah dan selama proses alam tersebut berlangsung. Akan tetapi dalam kehidupan manusia didefinisikan konsep lingkungan maka sampah dapat dibagi menurut jenis-jenisnya. Sampah yang selama ini cenderung menjadi suatu yang dipersoalkan karena tidak adanya nilai guna didalamnya sehingga tidak heran jika saat ini kita sering menjumpai barang-barang bernilai ekonomi yang dibuat dari bahan olahan sampah. Bank sampah merupakan suatu lembaga yang berfungsi menampung sampah yang diberikan oleh masyarakat yang nantinya akan diolah kembali untuk dijadikan barang-barang yang memiliki nilai ekonomi kembali dimasyarakat, sebagai imbal baliknya sampah-sampah yang dikumpulkan masyarakat sangat membantu dalam program kebersihan lingkungan. Dengan adanya kepedulian dari tokoh masyarakat dalam melestarikan lingkungan melalui pengelolaan sampah, juga sebagai upaya mengurangi polusi sampah anorganik dan gulma yang berupa eceng gondok yang tumbuh di sekitar sungai Citarum ada juga sebagai upaya melatih hidup sehat dan bersih bagi masyarakat. Sehingga setiap sampah yang dihasilkan masyarakat setiap hari tidak terbuang percuma atau bahkan sampah yang tadinya menjadi hal yang sangat diabaikan nantinya akan menjadi barang yang diperebutkan karena memiliki nilai ekonomi setelah diolah sedemikian rupa menjadi berbagai jenis kerajinan tangan harga jualnya sangat tinggi.
\end{abstract}

Kata Kunci : pemberdayaan; pengelolaan limbah

\begin{abstract}
Waste is a waste material that is not in want after the end of a process. Waste is defined by humans according to degrees of exposure, in natural processes there is no concept of waste, only the products produced after and during the natural process take place. But because in human life defined the concept of the environment then the garbage can be divided by the types. Garbage which has tended to become an issue because there is no use value in it even tends to be interpreted as goods whose existence so do not be surprised if today we often encounter goods of economic value made from processed waste materials. Bank waste is an institution that serves to accommodate the waste provided by the community which will be processed back to be used goods that have economic value back in the community, in return the garbage collected by the community is very helpful in the program of environmental hygiene. With the awareness of community leaders in preserving the environment through waste management, as well as efforts to reduce the pollution of inorganic waste and weeds in the form of water hyacinth that grows around the river Citarum there is also an effort to train healthy and clean life for the community. So every garbage generated by the community every day is not wasted or even garbage that had become a very neglected thing will be a contested item because it has economic value after being processed in such a way to be various types of handicrafts selling price is very high.
\end{abstract}

Keywords: empowerment; waste management

\section{PENDAHULUAN}

Pembangunan nasional dimaksudkan untuk membangun manusia Indonesia, sehingga pembangunan sebagai usaha peningkatan kualitas manusia dan masyarakat Indonesia yang dilaksanakan secara berkelanjutan, berlandaskan kemampuan nasional dengan memanfaatkan kemajuan ilmu pengetahuan teknologi serta memperhatikan tantangan perkembangan global. Dalam pelaksanaannya mengacu kepada kepribadian bangsa dan nilai luhur yang universal untuk mewujudkan kehidupan bangsa yang berdaulat, mandiri, berkeadilan, sejahtera, maju dan kukuh kekuatan moral etikanya. Pembangunan akan berhasil jika didukung oleh manusia yang terampil, cakap, dan bertanggung jawab serta dapat mengabdi kepada nusa dan bangsa. Dengan semakin bertambahnya penduduk usia produktif perlu dikembangkan potensi semaksimal mungkin, sesuai dengan tuntutan Negara yang tercantum dalam GBHN 1988, yaitu : “ jumlah penduduk 
yang sangat besar apabila di bina dan dikerahkan sebagai tenaga kerja yang efektif akan merupakan modal pembangunan di segala bidang". Tertarik dengan permasalahan di atas, terutama yang berkaitan dengan bagaimana upaya tokoh masyarakat dalam memberdayakan para pemulung yang bertempat tinggal di bantaran sungai citarum. Untuk itu penulis bermaksud mendalaminya malalui sebuah penelitian ilmiah yang dirumuskan ke dalam sebuah judul : "Pemberdayakan Masyarakat melalui pengelolaan Limbah Sungai Citarum di Kecamatan Lembang Kabupaten Bandung Barat". Kondisi sungai Citarum saat ini sangat memprihatinkan, dikarenakan masih banyak warga masyarakat yang kurang peduli terhadap kebersihan sungai Citarum dan terhadap kebersihan lingkungan. Tidak jarang masih banyak warga masyarakat yang sengaja membuang sampah ke sungai, begitu pula banyak pabrik-pabrik yang membuang limbah ke sungai, sehingga air di sungai citarum keruh dan kotor. Begitu pula selain sampah yang menumpuk di bantaran sungai, banyak pula tumbuhan seperti eceng gondok yang tumbuh subur, eceng gondok merupakan gulma yang sangat sulit untuk dibersihkan walaupun setiap hari dimusnahkan. Berangkat dari permasalahan di atas, perlu adanya upaya dan kepedulian dari berbagai pihak baik pemerintah maupun warga masyarakat untuk melakukan berbagai cara dalam penanggulangan sampah dan gulma tersebut. Salah seorang tokoh masyarakat warga desa Kecamatan Lembang berusaha membuat terobosan yaitu dengan cara mengumpulkan para pemulung untuk dibina dan dilatih melalui pemberdayaan masyarakat dalam mengola limbah sungai citarum baik limbah non organik maupun gulma untuk dijadikan berbagai cideramata atau kerajinan tangan yang memiliki nilai jual yang tinggi.

\section{KAJIAN TEORI}

\section{Konsep Pemberdayaan}

Pemberdayaan merupakan terjemahan dari empowerment, yang berasal dari kata "power" yaitu kekuatan. Istilah pemberdayaan dapat dikaitkan dengan proses transformasi sosial, ekonomi dan politik (kekuasaan). Konsep pemberdayaan pada dasarnya adalah upaya menjadikan suasana kemanusiaan yang adil dan beradab menjadi semakin efektif secara struktural, baik di dalam kehidupan keluarga, masyarakat, negara, regional, internasional dalam bidang politik, ekonomi dan lain-lain. Suzanne Kindevatter dalam bukunya Nonformal Education as an Empowering Process (1979) dalam Djudju Sudjana (2000:77), mengemukakan konsep pemberdayaan atau Empowering Process. Konsep ini bermakna bahwa "People gaining an understanding of and control over social, economic, and lor political forces in order to improve their standing in societv". Proses pemberian kekuatan atau pemberdayaan adalah setiap upaya pendidikan yang bertujuan membangkitkan kesadaran, pengertian, dan kepekaan peserta didik terhadap perkembangan sosial, ekonomi dan atau politik, sehingga pada gilirannya peserta didik memiliki kemampuan untuk memperbaiki dan meningkatkan status sosial, ekonomi dan politiknya dalam masyarakat. Pemberdayaan adalah proses membantu individu atau masyarakat dalam menciptakan pemahaman baru sekaligus memberi kebebasan untuk membuat pilihan. Dengan kata lain pemberdayaan adalah proses meningkatkan kekuatankekuatan dari dalam diri individu, seperti kompetensi dan kreativitasnya serta meningkatkan kebebasan orang tersebut dalam bertindak. Kesimpulan di atas mengungkapkan bahwa pendidikan, khususnya pendidikan luar sekolah, sebagai proses pemberdayaan adalah suatu pendekatan pendidikan yang bertujuan untuk meningkatkan pengertian dan pengendalian diri peserta didik terhadap kehidupan sosial, ekonomi dan/atau politik sehingga peserta didik mampu untuk meningkatkan taraf hidupnya dalam masyarakat. Untuk itu proses yang perlu ditempuh peserta didik adalah : (1) melatih tingkat kepekaan yang tinggi terhadap berbagai aspek perkembangan sosial, ekonomi dan politik selama proses pembelajaran, (2) mempelajari berbagai macam keterampilan untuk memenuhi kebutuhan dan untuk memecahkan masalah 
yang dihadapi, dan (3) bekerja sama dalam memecahkan masalah yang dihadapi bersama.

\section{Konsep Pelatihan}

Pelatihan adalah upaya untuk mengembangkan sumber daya manusia, terutama untuk mengembangkan kemampuan intelektual, keterampilan dan kepribadian manusia. Pelatihan (training) sering dikacaukan penggunaannya dengan latihan (practice atau exercise) ialah merupakan bagian dari suatu proses pendidikan, yang tujuannya untuk meningkatkan kemampuan atau keterampilan khusus seseorang atau kelompok orang. Dengan demikian dapat dikatakan bahwa pelatihan merupakan proses pembelajaran untuk meningkatkan kinerja orang-orang dalam menyelesaikan pekerjaan. Pelatihan adalah suatu proses yang menciptakan kondisi dan stimulus untuk menimbulkan respons terhadap orang lain, mengembangkan pengetahuan dan keterampilan (skill) dan sikap, menciptakan perubahan tingkah laku, dan untuk mencapai tujuan yang spesifik.

Pengertian mengenai pelatihan dikemukakan oleh French Ministery of Work, Employment and Profesional Training dalam Agus Dharma (1998 : 15) yang mengungkapkan bahwa :

"Pelatihan adalah aktifitas yang ditujukan bagi karyawan dan dilaksanakan pada tempat yang sesuai dengan program, serta memiliki tujuan yang jelas, metode pembelajaran yang spesifik, sasaran atau peserta yang jelas, rencana untuk untuk mengimplementasikan, penilalian terhadap hasil, dan termasuk di dalamnya adalah belajar, keamanan dan di luar keperluan pekerjaan".

\section{Tujuan Pelatihan}

Secara umum pelatihan menurut Moekijat, (1993 : 2-3) bertujuan untuk : 1) menambah keahlian,sehingga pekerjaan dapat diselesaikan dengan lebih cepat dan lebih efektif, 2) mengembangkan pengetahuan,sehingga pekerjaan dapat diselesaikan secara rasional, dan 3) mengembangkan menimbulkan kemauan kerja sama.
Menurut M. Saleh Marzuki (1992:18), merumuskan pelatihan ke dalam 3 (tiga) tujuan pokok, yaitu : 1) untuk memenuhi kebutuhan suatu organisasi, 2) melatui pelatihan peserta akan memperoleh pengertian dan pemahaman yang lengkap tentang pekerjaannya dengan standar dan kecepatan yang telah ditetapkan dan dalam keadaan aman dan normal, 3) membantu para pimpinan organisasi dalam melaksanakan tugasnya. Henry Simamora (1995 : 288) merumuskan ada 5 (lima) tujuan dari pelatihan, yaitu sebagai berikut: 1) Memutakhirkan keahilan para pegawai sejalan dengan perkembangan teknologi, 2) Mengurangi waktu belajar bagi pegawai baru untuk menjadi kompeten dalam suatu pekerjaan 3) Membantu memecahkan permasalahan operasional, 4) Mempersiapkan pegawai untuk suatu promosi tertentu, dan 5) Mengorientasikan pegawai terhadap organisasi.

\section{Manfaat Pelatihan}

Banyak pelatihan dilaksanakan dengan harapan dapat memberi manfaat. Beberapa manfaat seperti yang diungkapkan oleh Robinson (1981:19) dalam Saleh Marzuki M. (1992: 28) sebagai berikut:

1. Pelatihan sebagai alat untuk memperbaiki penampilan/kemampuan individu atau kelompok dengan harapan memperbaiki performance organisasi. Perbaikanperbaikan itu dapat dilaksanakan dengan berbagal cara. Pelatihan yang efektif dapat menghasilkan pengetahuan dalam pekerjaan/tugas, pengetahuan tentang struktur dan tujuan perusahaan/organisasi, tujuan bagianbagian tugas masing-masing karyawan dan sasarannya, tentang sistem dan prosedur, dan lain-lain.

2. Keterampilan tertentu diajarkan agar para karyawan dapat melaksanakan tugastugas sesuai standart yang diinginkan. Contoh : skill dalam menggunakan teknik yang berhubungan dengan fungsi "Behavioral skill " dalam mengelola hubungan dengan atasan (boss), dengan bawahan dan sejawat.

3. Pelatihan juga dapat memperbaiki sikapsikap terhadap pekerjaan, terhadap pimpinan atau karyawan, seringkali pula 
sikap-sikap yang tidak produktif timbul dan salah pengertian yang disebabkan oleh informasi yang tidak cukup, dan informasi yang membingungkan. Karena itu salah satu pemecahannya dalam kebijakan pelatihan dituj ukan pada penjelasan tentang fakta-fakta secara jujur.

4. Manfaat lain dari pada pelatihan adalah memperbaiki standar keselamatan. Di salah satu perusahaan listrik dilaporkan bahwa pelatihan telah banyak membantu memperbaiki keselamatan dari bahaya aliran listrik.

Dengan demikian pelatihan merupakan sarana yang ditujukan pada upaya untuk lebih mengaktifkan kerja para pegawai organisasi yang dipandang kurang aktif sebelumnya, mengurangi adanya dampak negatif yang disebabkan kurangnya pengetahuan, kurangnya kepercayaan diri atau pengalaman yang terbatas dari anggota atau kelompok tertentu. Dalam pengembangan pelatihan sumber manusia jelas pelatihan mutlak diperlukan, kemutlakan itu tergambar pada berbagai jenis manfaat yang dapat diambil dah padanya, baik bagi organisasi atau kelompok masyarakat, bagi para pegawai atau peserta pelatihan maupun bagi penumbuhan dan pemeliharaan hubungan yang serasi baik dalam berbagai kelompok kerja maupun antara peserta di dalam kelompok, yang semuanya diharapkan bermuara pada peningkatan produktifitas.

\section{Komponen-Komponen Pelatihan}

Istilah pelatihan sebenarnya tidak terlepas dari kegiatan pembelajaran yang dapat dilakukan dengan berbagai cara atau teknik. Di samping komponen yang ada dalan sistem pembelajaran seperti : tujuan yang ingin dicapai, materi yang digunakan, kegiatan belajar mengajar, alat bantu/media yang digunakan dan pelatihan, juga menggunakan teknik yang banyak dikenal masyarakat pada saat ini disebut "Teknik Empat Langkah. Urutan langkah-langkah dalam teknik ini adalah "Memperlihatkan (to show) - Menjelaskan (to tell) - Mengenakan (to do) - Memeriksa (to check)". (Djudju Sudjana, 2000 : 13). Komponen dalam menyelenggarakan pelatihan sebagai suatu satuan pendidikan luar sekolah yang satu sama lainnya saling berkaitan, secara rinci dapat dijelaskan sebagai berikut:

1. Masukan sarana (instrumental input) meliputi keseluruhan sumber dan fasilitas yang memungkinan bagi seseorang atau kelompok dapat melakukan kegiatan belajar.

2. Masukan mentah (raw input) yaitu peserta didik (warga belajar) dengan berbagai karakteristiknya yang dimilikinya.

3. Masukan lingkungan (environmental input) yaitu faktor lingkungan yang menunjang atau mendorong berjalannya program pendidikan.

4. Proses (process) yang menyangkut interaksi antara masukan sarana, terutama pendidik dengan masukan mentah, yaitu peserta didik (warga belajar).

5. Keluaran (out put) yaitu kuantitas lulusan yang disertai dengan kualitas perubahan tingkah laku yang didapat melalui kegiatan belajar membelajarkan.

6. Masukan lain (other input) adalah daya dukung lain yang memungkinkan para peserta didik dan lulusan dapat menggunakan kemampuan yang telah dimiliki untuk kemajuan kehidupannya.

7. Pengaruh (impact) yang menyangkut hasil yang telah dicapai oleh peserta didik dan lulusan.

\section{PEMBAHASAN}

\section{Unit Daur Ulang Sampah Plastik}

Lokasi kegiatan pemberdayaan masyarakat melalui Daur Ulang Limbah Plastik dan eceng gondok khusus yang berada di Kecamatan Lembang yaitu sebanyak 50 orang. Mereka setiap hari mengambil sampah plastic dan eceng gondok dari sungai citarum dan Waduk Saguling dan menjualnya. Bersama untuk diolah dan selanjutnya setelah diolah lalu dijual ke pabrik pengolahan biji plastic, sedangkan eceng gondok diolah menjadi berbagai jenis kerajinan tangan berupa cinderamata yang siap dijual dan memenuhi pesanan/ permintaan dari berbagai daerah. 


\section{Volume Sampah Yang Terangkut}

Jenis jenis sampah yang mampu diangkat dari dari waduk saguling adalah jenis sampah plastik yang memiliki nilai ekonomi atau laku dipasaran. Dibanding tahun tahun 2015, maka volume sampah yang mampu terangkat dari berbagai anak sungai citarum pada tahun 2016 mengalami penurunan drastic sebanyak $23.5 \%$, yaitu tahun 2015 rata rata sampah terangkat sebanyak $104.540 \mathrm{~kg} / \mathrm{bulan}$ sementara pada tahun 2016 rata rata sampah yang mampu terangkat hanya sebanyak $79.947 \mathrm{~kg} / \mathrm{bulan}$.

Menurunnya jumlah tangkapan sampah diprediksi oleh beberapa hal diantaranya :

1. Adanya gerakan Citarum Bestari dengan Ecovillage yang dilakukan oleh Pemda Provinsi Jawa Barat di wilayah hulu Citarum, sehingga sampah yang masuk inlate saguling berkurang.

2. Adanya Gerakan gerakan yang dilakukan oleh komunitas Bank Sampah baik di kota Bandung, Cimahi, Kabupaten Bandung dan Bandung Barat.

\section{- Green School}

Green School adalah program pelestarian Citarum berbasis sekolah yang dekat dengan sungai citarum, tujuan dari program ini adalah edukasi dan pembentukan kader lingkungan berbasis sekolah dimana sampaah di sekolah tidak lagi dibakar atau dibuang ke sungai Citarum melainkan diolah langsung di sekolah. Dimana sampah organik dijadikan kompos untuk kebutuhan kompos dan dapat dimanfaatkan untuk menanam bunga bunga atau sayuran di sekolah sementara sampah anorganikya dijadkan tabungan karena di setiap sekolah yang mendapat program ini

\section{REFERENSI}

Hikmat, H (2013) Strategi Pemberdayaan masyarakat. Bandung : Humaniora Utama.

Comb, H \& Manzoor,A. (1973). Memerangi Kemiskinan di Pedesaan Melalui Pendidikan Non Formal. Bank dunia. dibentuk Bank Sampah Sekolah. Produk

\section{Pemberdayaan}

Hasil dari kegiatan pengumpulan sampah yang dilakukan oleh masyarakat dari tiga desa, berupa plastik dikumpulkan dan dibersihkan serta dipilah-pilah jenisnya, untuk dijadikan berbagai cindera mata. Sedangkan gulma yang terdiri dari tanaman eceng gondok setelah dikeringkan diolah untuk dijadikan berbagai macam kerajinan tangan berupa tas, kantong gendong, tikar dan sebagainya.

\section{KESIMPULAN}

Melalui perberdayaan masyarakat terhadap para pemulung yang ada di bantaran sungai citarum, terdapat perubahan pola pikir masyarakat ke arah yang lebih baik, dikarenakan ada kepedulian dari tokoh masyarakat dan perhatian dari pemerintah provinsi diantaranya sebagai berikut:

1. Adanya gerakan Citarum Bestari dengan Ecovillage yang dilakukan oleh Pemda Provinsi Jawa Barat di wilayah hulu Citarum, sehingga sampah yang masuk inlate saguling berkurang.

2. Adanya Gerakan gerakan yang dilakukan oleh komunitas Bank Sampah baik di kota Bandung, Cimahi, Kabupaten Bandung dan Bandung Barat.

3. Bank sampah telah menjadi model dan objek penelitian berbagai pihak guna dijadikan model pelestarian berbasis pemberdayaan oleh beberapa pihak yang berkepentingan.

4. Sejak berdiri tahun 2009 sampai dengan sekarang, Bank Sampah telah berkiprah bukan saja di daerah inlate saguling, tapi sudah merambah ke daerah hulu Citarum dalam upaya pelestarian Citarum.

Kaswan \& Ade Sadikin. (2015) Pengembangan Sumber Daya

Manusia, Alfabeta, Bandung

Kindervatter, S. (1979). Non Formal Education As An Empowering Process With Studies From.

Sudjana. D (2000). Manajement Program Pendidikan Untuk Pendidikan Luar Sekolah dan Pengembangan Sumber 
Deni Darmawan ${ }^{1}$ Rita Setiawati ${ }^{2}$,Sekar Hana Triesti $K^{3}$, Ridho Anggoro ${ }^{4}$, Andy Surya $A^{5} /$ Pemberdayaan Masyarakat Melalui Pengelolaan Limbah di Anak Sungai Citarum

Daya Manusia. Bandung: Falah Production.

Sakai, M. (1999) Current Research Status Of Fish Immunostimulants. Cuaculture (136. P21-29

Marzuki Sales. (2012) Pendidikan Non Formal, Rosda Karya,bandung 